\title{
ATRAUMATIC ISCHAEMIC MYELOPATHY
}

\author{
By L. S. Kewalramani, M.D., M.S. Orth. and R. S. R. Katta, M.D. \\ Louisiana Rehabilitation Institute, LSU School of Medicine New Orleans, Louisiana and \\ Baylor College of Medicine, Houston, Texas
}

\begin{abstract}
Significant and permanent neurological deficit due to ischaemic myelopathy continues to occur in 5-Io per cent of patients following surgery on the thoracic aorta for aneurysms, coarctation and lacerations, and following corrective surgery for scoliosis. Clinical features, patterns of neurological deficit, management and outcome in 29 patients with atraumatic ischaemic myelopathy following surgery on the aorta, aortocoronary bypass and cardiogenic shock, will be presented. Pertinent literature on the subject will also be reviewed.
\end{abstract}

Key words: Secondary (non-traumatic neurological) ischaemic myelopathy; Aortic injury; Aortic aneurysms; Aortocoronary bypass surgery.

\section{Introduction}

INFARCTION of the spinal cord has been considered to be rare when compared with cerebral infarction (Garland et al., I966) which may be due to the fact that the frequency of arteriosclerotic changes in major spinal arteries occur in $2 \cdot 2-10$ per cent of cases compared with cerebrovascular arteriosclerotic changes in 39 per cent of the population (Jellinger, I967). Although Bastian in I9IO was first to suggest that spinal cord softening might be a consequence of vascular occlusion but for several years the number of well documented cases of ischaemic myelopathy remained small and often anecdotal with syphilitic vasculitis. There continued to be limited interest in the spinovascular syndromes until neurological deficit following surgery on the thoracic aorta brought into sharp focus the role of vascular occlusions and ischaemic injury to the spinal cord. Ischaemic myelopathy has been associated with dissecting aneurysm of the aorta, myocardial infarction with cardiogenic shock, cardiac arrest, Stokes-Adams Syndrome, systemic lupus erythematosus, aortic atherosclerosis and cholesterol embolism. This continues to be an important complication following surgery for resection of aneurysm, coarctation and repair of traumaticlacerations of the thoracic aorta. Following corrective surgery for scoliosis, this complication has been reported to occur in $\mathrm{I}-6$ per cent of cases (Dommisse, 1974). Several authors have erroneously used the term 'anterior spinal artery syndrome' to describe these infarcts regardless of the cause, because of the presence of flaccid paralysis, absence of deep tendon reflexes and some preserved sensation (Turnbull, 1972)... The objective of this paper is to report a series of 29 patients with ischaemic myelopathy of various aetiologies and critically analyse their neurological features, pathogenesis and outcome. Pertinent literature on the subject will also be reviewed.

Address for Reprints: L. S. Kewalramani, M.D., M.S. Orth., Louisiana Rehabilitation Institute, LSU School of Medicine, 1542 Tulane Avenue, New Orleans, Louisiana 70II2, U.S.A. 


\section{Materials and Methods}

Medical records of 29 patients with atraumatic noncompressive ischaemic myelopathy were exhaustively reviewed. Patients with myelopathy associated with lupus erythematosus, viral infection, and radiation therapy were excluded from the series. Approximately 75 per cent of patients were seen and followed by the authors personally. For classification of the functional outcome, patients were grouped as follows:

o. No sensory/motor change

I. Motor and/or sensory improvement, non-functional

2. Motor/sensory improvement, functional with orthosis

3. Motor/sensory improvement, functional without orthosis

4. Complete functional recovery with/without abnormal reflexes

\section{Findings}

There were 2 I males and eight females, from 26 to 75 years of age.

Four patients with laceration of thoracic aorta (Table I) had no neurological deficit at the time of admission. All were involved in automobile collisions and were admitted complaining of chest pain. Because of the presence of a wide mediastinum and suspicion of aortic laceration, they underwent aortic angiography and were found to have laceration of the descending thoracic aorta, distal to the takeoff of the left subclavian artery. All developed paraplegia below T6 following the surgical repair of the aorta.

The I2 patients with dissecting aneurysms of the aorta (Table II) were admitted complaining of sudden sharp pain in the upper part of back, interscapular region, and/or epigastric regions with radiation to shoulder blades, but no neurological deficit. On aortic angiography dissecting aneurysm of descending thoracic aorta was confirmed in all cases. Following surgery five patients were found to have complete sensory and motor loss below $\mathrm{T}_{4}-8$; while other seven had incomplete motor and sensory lesions.

Of the eight patients with aneurysms of the thoracic aorta (Table III), four presented with chronic complaints of pain-left side chest and shoulder, epigastric and/or mid scapular region. One patient was admitted complaining of dysphagia. Other two patients were known to be hypertensive. On evaluation these patients were found to have thoraco-abdominal aneurysms and underwent aneurysmectomy and repair with graft. These seven patients developed neurological deficit following surgery. Only one of eight patients with aneurysm of descending aorta had neurological deficit ( $\mathrm{T}_{4}$ complete paraplegia) of 3 days' duration at the time of admission. Two patients had complete loss of sensation and motor function below the level of lesion at $\mathrm{T}_{4}$ and $\mathrm{T} 6$, and other six had incomplete sensory and motor lesions.

One patient developed sudden numbness and weakness in lower limbs; over a period of 30 minutes became completely paraplegic; and had a normal aortogram. Another patient was admitted with acute chest pain due to myocardial infarction and cardiogenic shock, but no neurological deficit. This patient underwent intraaortic balloon placement; he developed aorto-iliac occlusion for which he required aortofemoral bypass and developed paraparesis below TI2. Two patients underwent elective aortocoronary bypass, and following surgery developed paraparesis (Table IV).

The clinical features of all cases are summarised in Tables I-IV. 
PARAPLEGIA

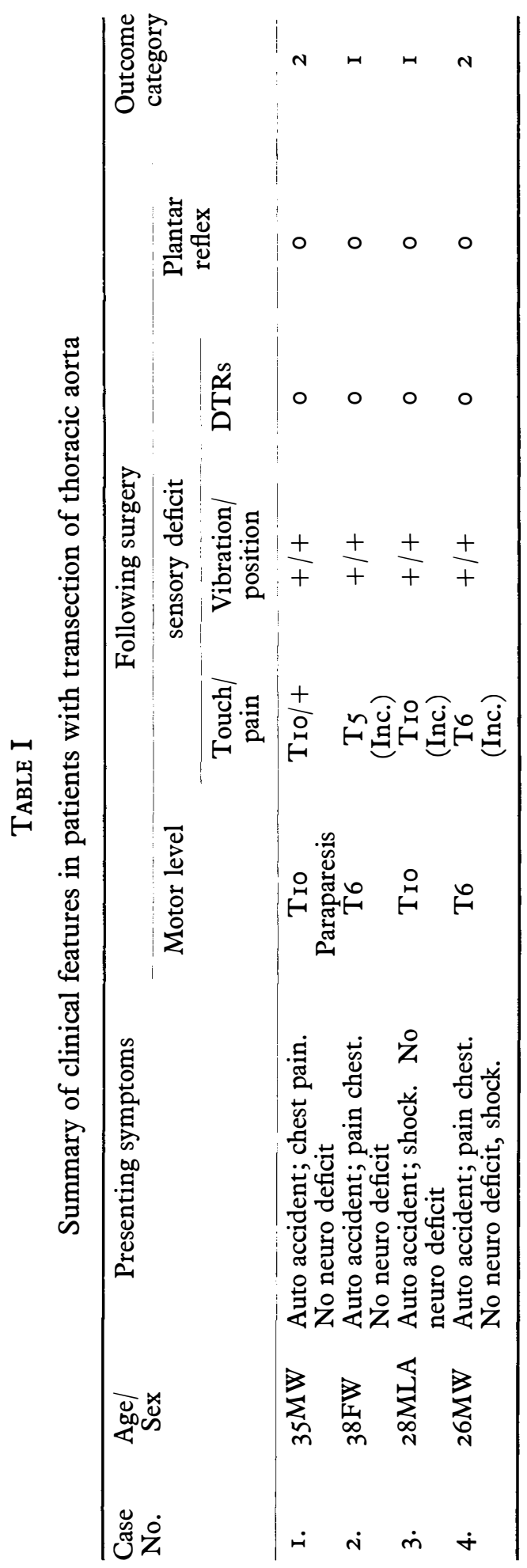




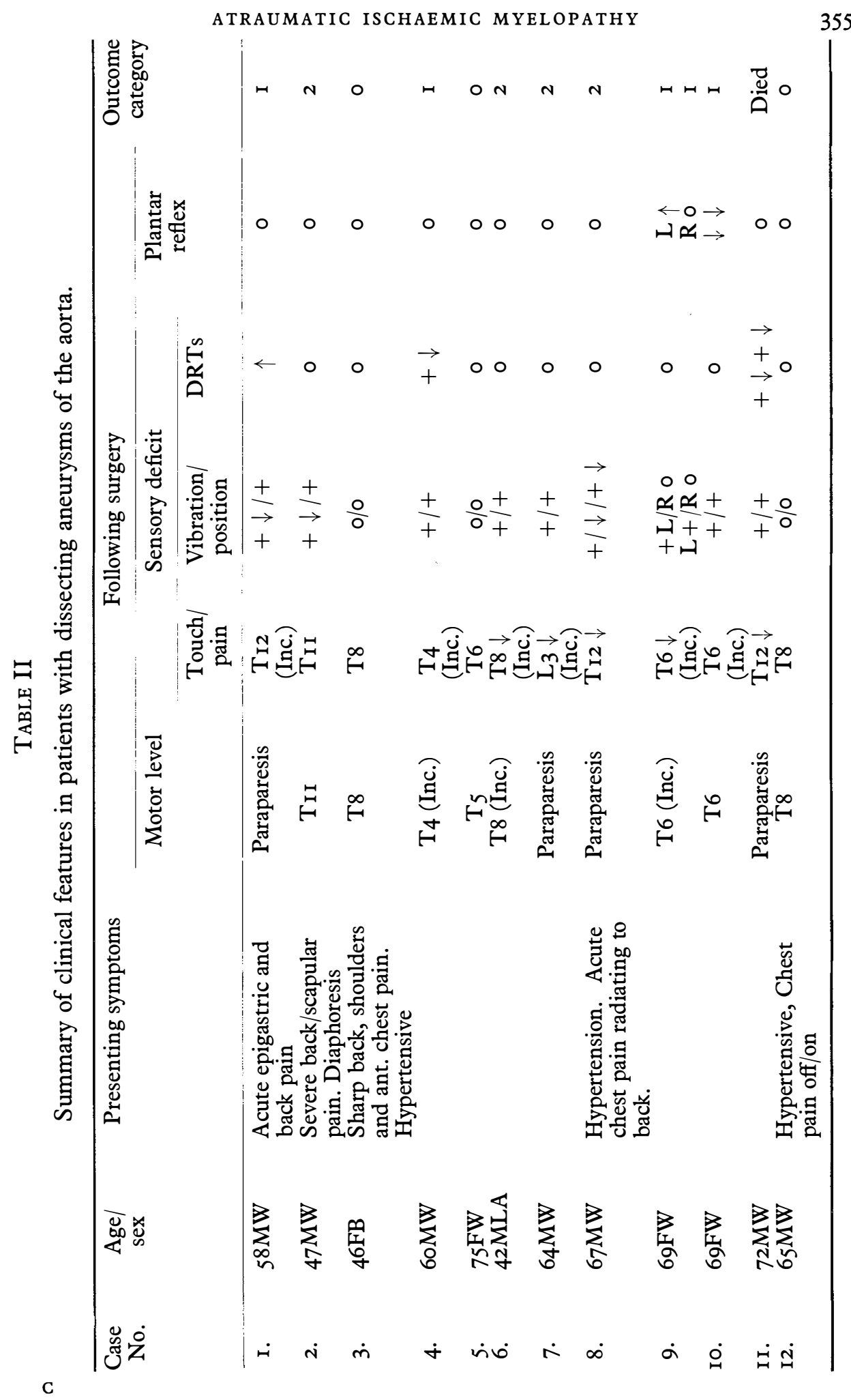


PARA PLEG IA

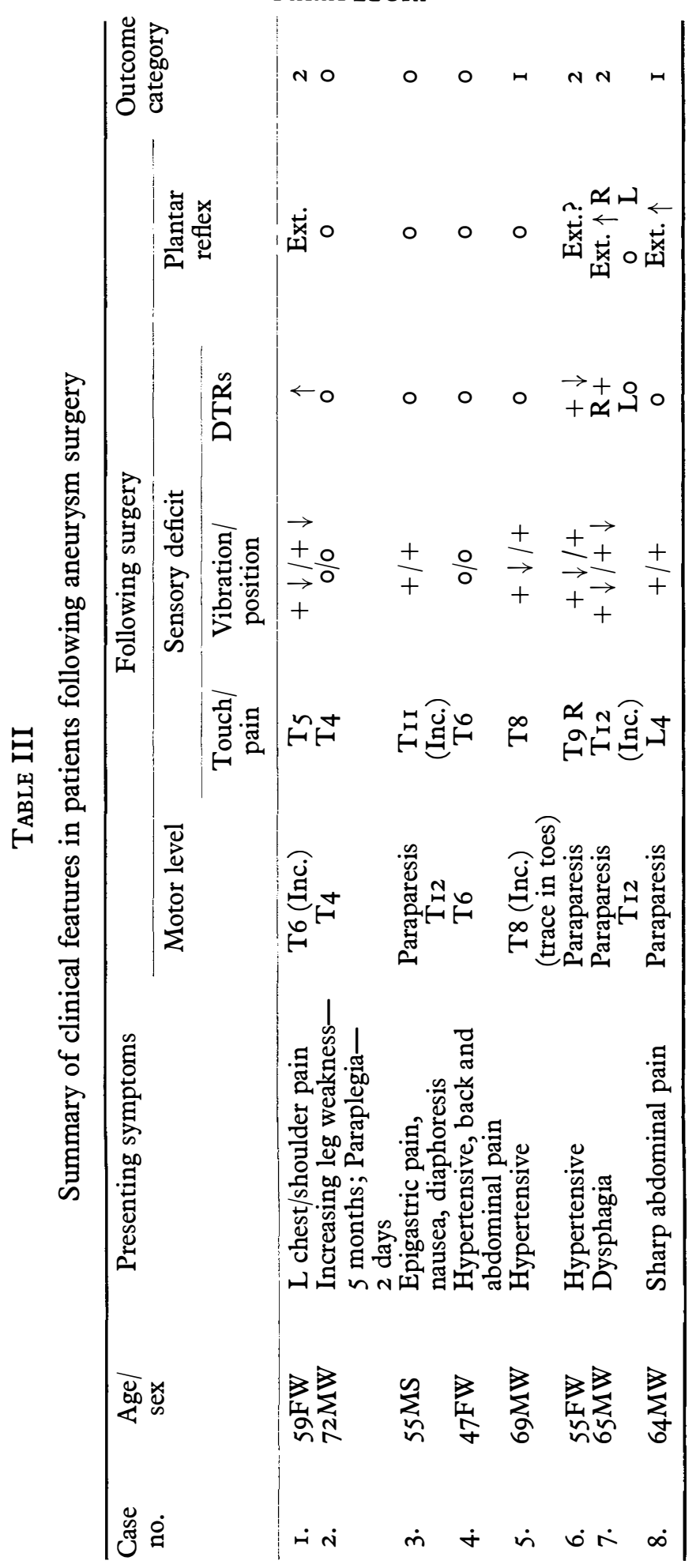




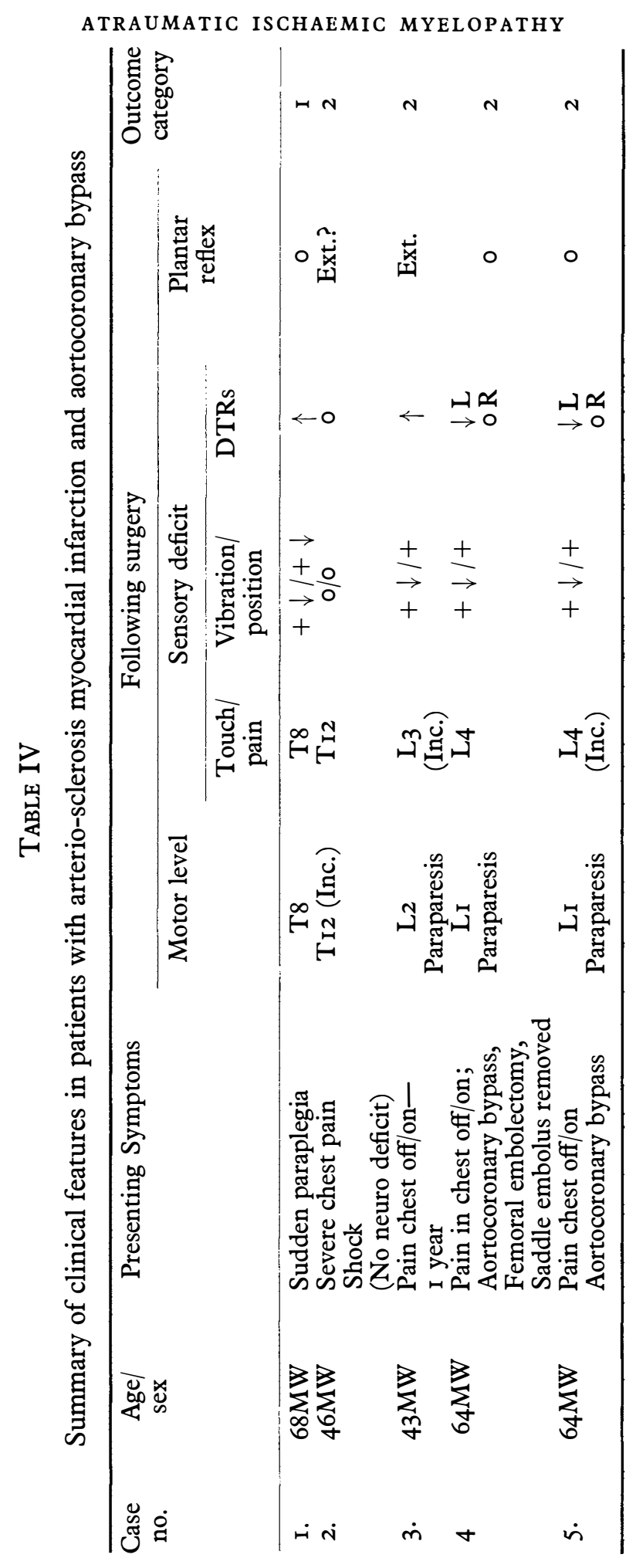




\section{Discussion}

The total number of cases of arteriovascular injuries to the spinal cord is very small in relation to other aetiological processes. However, ischaemic myelopathy following surgery on the thoracic aorta, cardiogenic shock, coronary bypass and correction of scoliosis continues to be an important post-operative complication in a number of patients. The reports of ischaemic damage to the spinal cord provide scattered and conflicting data about the anatomy of its blood supply, its vulnerability to inadequate perfusion, and the measures required to prevent neurological complications after procedures on the aorta (Pasternak et al., 1972). Extensive review of the literature reveals that this complication appears to be beyond the control of vascular surgeons, and might occur in any case. It is essential that patients undergoing aortic surgery be informed about this complication.

It is estimated that the incidence of ischaemic myelopathy following surgery on thoracic aorta for coarctation, aneurysms and dissecting aneurysm is 0.5 per cent (Blaisdell \& Cooley, 1962, Brewer et al., 1972, Pasternak et al., 1972, Crawford \& Rubio, I973, Reul et al., I975). Adams \& Van Geertruyden (I956) reviewed 24 cases of ischaemia of the spinal cord associated with aortic surgery and reported that flaccid or spastic paraplegia in at least 80 per cent of patients was permanent. Ellis et al. (1958) reported only one case of postoperative weakness of lower limbs following aneurysmectomy in I5 patients. Crawford \& Rubio (I973) had only four patients with paraplegia out of 83 patients operated on for thoracic aortic aneurysms distal to the common carotid artery. Three of these four patients were in hypovolemic shock, and the fourth patient developed spinal cord damage 4 days after the resection of aneurysm following a period of hypotension. These authors also found 'shunting' of no value in preventing the ischaemic damage to the cord, since patients who underwent surgery with shunting were found to have a higher incidence of paraplegia. There is considerable controversy regarding the cause of ischaemia of the spinal cord. Prolonged cross clamping of aorta, mobilisation of the aorta and division of a large number of intercostal vessels (Killen et al., 1965), and hypotension with low rate of flow to the collateral arteries (Pasternak et al., I972, Crawford, 1974) have been considered to be responsible for myelopathy. However, some authors feel that neither the sacrifice of intercostal arteries, nor the time of occlusion of the aorta was related to spinal cord ischaemia in all cases (Brewer et al., I972). The common feature in all these situations is reduced perfusion of the spinal cord and infarction. Systemic blood pressure has been shown in animals to be the most important factor controlling blood flow in the vessels of the spinal cord (Field et al., I95I) and paraplegia has been observed in man following hypotension (Madow \& Alpers, I949, Crawford \& Rubio, I975, Spencer, I976). However, nothing is known about the 'critical' minimum blood pressure in the capillary bed of the human spinal cord, where blood flow reaches critical levels, $\mathrm{O}_{2}$ uptake begins to decrease and results in neurological disturbances. Very little is known about the autoregulation of blood flow to the spinal cord. We feel that hypotensionduring or after surgery is the primary factor in the onset of ischaemic myelopathy, and the severity and duration of hypotension coupled with individualvariations in the spinal arterial network dictate the severity and transient or permanent nature of the neurological deficit.

There were only two patients in the present series of 29 who had neurological deficit at the time of admission, while other 27 patients developed significant sensory and motor loss following surgery. Twenty-one of these 29 patients ( 74 per 
cent) had some preservation of posterior column functions and/or pain and temperature. Fifty-five per cent of patients had some preservation of voluntary motor activity in the lower limbs. Deep tendon reflexes in lower limbs were brisk in five patients immediately after the onset of paralysis, hypoactive in four and absent in 20 patients (70 per cent). On follow-up only three of 29 patients developed spasticity in the lower limbs and ankle clonus; while I 5 patients remained flaccid. The striking absence of spasticity, despite the presence of severe weakness might be explained by the presence of ischaemic lesion extending over a length of many segments of the spinal cord that had interrupted the reflex arc concerned with muscle stretch (Wolman \& Bradshaw, 1967). Nine patients showed useful motor and sensory return in the lower limbs and were able to ambulate with braces. Twelve patients showed some motor improvement, but this was non-functional. The neurological status of eight patients remained unchanged. Eight patients developed adequate voluntary control of their bladder and bowel functions, and they were able to void with low residuals and occasional incontinence. Ten male patients following an intermittent catheterisation programme developed reflex voiding and were free of indwelling catheters. Five male and six female patients had indwelling catheters. Since most of the publications on ischaemic myelopathy following surgery on the aorta have little information about the neurological patterns of deficit, we are unable to compare the present series with any other series.

Stripping off of the dorsal and lumbar segmental arteries by dissecting aneurysm (Moersch \& Sayre, I950, Thompson, 1956) has been a commonly accepted cause of sudden neurological deficit but in the present series none of the I2 patients with dissecting aneurysm had neurological deficit prior to surgery. Similarly only one of the five patients with dissecting thoracic aorta was reported by Hunter et al. (1976); and only one of 23 patients reported by Crawford \& Rubio (I973) had preoperative paraplegia.

Crawford \& Rubio (I973) have alluded to the fact that in patients with congenital or acquired diseases which develop slowly, the reduction in blood supply to the cord is gradual and normal function may be maintained by collateral channels, that would permit resection of descending thoracic aortic aneurysms in most cases. But, in acute dissecting aneurysms and trauma, time may not permit development of collateral circulation, and the period of hypotension and resection in the absence of collaterals may add to ischaemia of the spinal cord. In the present series, of the eight patients with aneurysm surgery, six had incomplete sensory and motor lesions. On the other hand, of the 12 patients with dissecting aneurysms following surgery four had complete sensory and motor loss; two had complete motor loss with preservation of posterior column functions and other six had incomplete motor and sensory loss; and one had some motor preservation. These findings, although in small series, indicate that the patterns and severity of neurological deficit following surgery in acute and chronic aortic lesions are not different. The functional outcome in these two groups was also similar.

We were able to find only one case of massive infarction of the spinal cord and vertebral bodies associated with dissecting aneurysm (Hill \& Vasquez, I962). In the present series, of the I 2 patients with dissecting aortic aneurysm, one patient (Case \#2) 2 months following the onset of TII paraparesis, was found to have wedging of $\mathrm{T}_{9}$ vertebral body and patchy sclerosis of anterior half of vertebra which were not present on the initial X-ray films. It is difficult to say if this was caused by ischaemia of the vertebral body or caused by trauma, though the patient 
denied any history of injury to his spine. We agree with Hill \& Vasquez (I962) that in all cases of dissecting aneurysm exhibiting neurological deficit, vertebral bodies should receive thorough study.

\section{SUMMARY}

Significant neurological deficit due to ischaemic myelopathy continues to be an important complication following resection of aneurysms, repairs of lacerations of descending thoracic aorta and corrective surgery for scoliosis. Because of the presence of flaccid paralysis, absent deep tendon reflexes and some preserved sensation, several authors have erroneously used the term 'anterior spinal artery syndrome' to describe these infarcts, regardless of the cause. Medical records of 29 patients (2I males \& eight females) with ischaemic myelopathy with a follow-up of $\mathrm{I}$ to 4 years, were exhaustively reviewed. On admission 27 of 29 patients were recorded to have normal neurological examination. Inmediately following surgery for dissecting aneurysm of thoracic aorta ( 12 cases), aneurysmectomy (eight cases), repair of laceration of descending thoracic aorta (four cases) and aortocoronary bypass (two cases), these patients were found to have significant neurological deficit. Fifty-five per cent of patients had some voluntary motor function in the lower limbs and 74 per cent had preservation of touch, pain, vibration and position sense in the lower limbs. Deep tendon reflexes at the onset of paralysis were absent in 70 per cent. Only a third of these patients showed useful neurological return and were able to ambulate with braces. Twenty-seven per cent of patients developed adequate voluntary control of bladder function. Careful analysis of neurological patterns of deficit i.e., some preservation of all sensory modalities, and some motor preservation, favours the possibility of tissue perfusion defect rather than occlusion of radicular and anterior spinal arteries. Pertinent literature on the subject is also extensively reviewed.

\section{RÉSUMÉ}

Une déficience neurologique significative due à une myelopathie ischémique continue d'être une importante complication à la suite d'une résection d'anévrisme, de soins de lacérations de l'aorte thoracique descendante et d'une chirurgie corrective de la scoliose. A cause de la presence d'une paralysie flasque, de réflexes du tendon fort profond manquant et de quelque sensation restante, plusieurs auteurs ont utilisé à tort le terme "syndrome de l'artère spinale antérieure" pour décrire ces infarctus sans se soucier de la cause. On a passé en revue de manière approfondie les dossiers médicaux de 29 patients (2I hommes et 8 femmes) ayant une myelopathie ischémique avec un suivi duré à quatre années. A l'admission, on a enregistré 27 patients ayant un examen neurologique normal parmi les 29. Immédiatement après l'opération de dissection de l'anévrisme de l'aorte thoracique (13 cas), d'anévrismectomie ( 18 cas), des soins par lacération de l'aorte thoracique descendante (4 cas) et de portage aorto-coronaire ( 2 cas), ces patients s'averaient avoir une déficience neurologique significative. Cinquante-cinq pour cent $(55 \%)$ des patients eurent des réserves de sursauts moteurs volontaires dans les membres inférieurs at $74 \%$ conservèrent la sensation de toucher, de douleur, de vibration et de position dans les membres inférieurs. Les réflexes au niveau du tendon profond lors de l'attaque de paralysie étaient inexistants à $70 \%$. Seul un tiers de ces patients operèrent un rétablissement neurologique et furent capables de déambuler avec des armatures orthopédiques. Vingt-sept pour cent $(27 \%)$ des patients developèrent un controle volontaire et adequat de la fonction urinaire. Une analyse minutieuse d'exemple neurologique de déficience, c'est à dire, la conservation de toutes des modalités sensorielles et motrices en partie, indique plûtot la possibilité de défectuosité de la perfusion du tissu que l'occlusion des artères spinales radiculaires et antéeriures. On a passé également en revue une vaste documentation à ce sujet. 


\section{ZUSAMMENFASSUNG}

Bedeutendes neurologisches Defizit auf grund ischämischer Myelopathie bleibt weiterhin eine wichtige Komplikation nach Aneurysma-Resektion, Operationen nach Verletzungen der absteigenden thorakalen Aorta und Skoliose-Operationen. Wegen der schlaffen Lähmung, Abwesenheit der tiefen Sehnen-Reflexen und teilweise erhaltener Sensation benutzen verschiedene Autoren irrtümlicherweise die Bezeichnung "Anteriores Spinal-Arterien-Syndrom" um diese Infarkte zu beschreiben, ohne die Ursache in Betracht zu ziehen. Medizinische Berichte von 29 Patienten (2I männlich und 8 weiblich) mit ischämischer Myelopathie, die I bis 4 Jahre unter Beobachtung waren, wurden ausgiebig studiert. Bei der Aufnahme zeigten 24 von 29 Patienten normale neurologische Befunde. Direkt nach der Operation von Aneurysmadissketion der thorakalen Aorta (13 Fälle), Aneurysmektomie (8 Fälle), Riss und Reparatur der absteigenden thorakalen Aorta (4 Fälle) und aorto-coronarem Bypass (2 Fälle) wurden bedeutende neurologische Defizite in diesen Patienten gefunden. In $55 \%$ der Patienten war etwas willkürliche Bewegung erhalten in den unteren Gliedern und in $14 \%$ war Berührungs-, Schmerz-, Vibrations- und Lagesinn der unteren Glieder erhalten. Am Anfang der Lähmung waren tiefe Sehnenreflexe in $70 \%$ abwesend. Nur ein Drittel dieser Patienten zeigte eine nutzbare Verbesserung des neurologischen Befundes und war in der Lage mit Schienen zu laufen. $27 \%$ der Patienten entwickelten ausreichende willkürliche Kontrolle ihrer Blasenfunktion. Sorgfältige Analyse der neurologischen Erscheinungsbilder, d.h. eine gewisse Erhaltung in allen sensorischen Kategorien und gewisse motorische Funktionen begünstigt die Möglichkeit eines Gewebe-Perfusionsdefekts an Stelle einer Okklusion der radialen und anterioren Spinalarterien. Entsprechende Literatur zu diesem Thema wurde weitgehend untersucht.

\section{REFERENCES}

Adams, H. D., and van GeERTRyden, H. H. (1956). Neurologic complications of aortic surgery. Ann Surg., 144, 574-610.

Bastian, H. C. (I883). Diseases of the spinal cord. In R. QuAIN, (ed.), A Dictionary of Medicine including General Pathology, General Therapeutics, Hygiene and the Diseases Peculiar to Women and Children, by various writers. New York, N.Y. D. Appleton Company pp. I456-I 466.

Blaisdell, F. W. and Cooley, D. A. (I962). The mechanism of paraplegia after temporary thoracic aortic occlusion and its relationship to spinal fluid pressure. Surgery, 5I, $35 \mathrm{I}-355$.

Brewer, III, L. A., Fosburg, R. G., Mulder, G. A. and Verska, J. J. (1972). Spinal cord complications following surgery for coarctation of the aorta-A study of 66 cases. F. Thoracic and Cardiovasc. Surg., 64, 368-38I.

CRAWFORD, E. S. \& RUBIO, P. A. (I973). Reappraisal of adjuncts to avoid ischemia in the treatment of aneurysms of descending thoracic aorta. F. Thorac. Cardiovasc. Surg., 66, 693-704.

CRAWFORD, E. S. (1974). Thoraco-abdominal and abdominal aortic aneurysms involving renal, superior mesenteric and coeliac arteries. Ann. Surg., 179, 763-772.

Dommisse, G. F. (1974). The blood supply of the spinal cord-A critical vascular zone in spinal surgery. F. Bone and foint Surg., 56B, 225-235.

Ellis, F. H., KIRKLIN, J. W. \& BREWER, A. J. (I958). Surgical experiences in the treatment of aneurysm of the thoracic aorta. Surg. Gynecol Obst., 106, I79-192.

Field, E. J., Grayson, J. \& Rogers, A. F. (I95I). Observations on the blood flow in the spinal cord of the rabbit. F. Physiol., 114, 56-70.

GarLand, H., GREENBERG, J., \& HARRIMAN, D. G. F. (1966). Infarction of the spinal cord. Brain, 89, 645-662.

HILL, C. S. \& VASQUEZ, J. M. (1962). Massive infarction of spinal cord and vertebral bodies as a complication of dissecting aneurysm of the aorta. Circulation, 25, 997-1000.

Hunter, J. A., Dye, W. S., Javid, H., Najafi, H., Goldin, M. D. \& Serry, C. (I976). Abdominal aortic resection in thoracic dissection. Arch. Surg., III, I258-1262.

JELLINGER, K. (1967). Spinal cord arteriosclerosis and progressive vascular meylopathy. f. Neurol. Neurosurg. Psychriat., 30, 195-206.

Killen, D. A., EDwards, R. H., AdKINS, R. B. et al. (1965). Spinal cord ischemia following mobilisation of canine aorta from posterior parietes. Ann. Surg., 162, 1063-1068.

MADOW, L. \& AlPERS, B. J. (I949). Involvement of the spinal cord in occlusion of the coronary vessels. Arch. Neurol. Psychiat., 61, 430-440. 
Moersch, F. P. \& SAYre, G. P. (I950). Neurologic manifestations associated with dissecting ameurysm of the aorta. $\mathcal{F} A M A, \mathbf{1 4 4}$, II 4 I-I I 48 .

PASTERnAK, B. M., Body, D. P. \& ElLIS, H. F. (I972). Spinal cord injury after procedures on the aorta. Surg. Gynecol. Obstet., 135, 29-34.

Reul, G. J., Cooley, D. A., Hallman, G. L. et al. (1975). Dissecting aneurysm of the descending aorta. Arch. Surg., I Io, 632-640.

SPENCER, F. C. (1976). Discussion on paper of Wakabayashi, A. \& Connolly, J. E. Arch. Surg., III, I I 86-I I 89 .

Thомpson, G. B. (1956). Dissecting aortic aneurysm with infarction of the spinal cord. Brain, 79, II I-I I 8 .

TURNBulL, I. M. (I972). Blood supply of the spinal cord. In Handbook of Clinical Neurology, edited by P. J. Vinken \& G. W. Bruyn, vol. I2, chapter I8. North Holland Publishing Company, Amsterdam.

Wolman, L. \& Bradshaw, P. (1967). Spinal cord embolism. F. Neurol. Neurosurg. Psychiat., 30, 446-454. 